\title{
STRUCTURE OF SMALL RODENT COMMUNITIES IN OR- CHARDS FROM THE CENTRAL PART OF THE REPUBLIC OF MOLDOVA AND BACAU DISTRICT, ROMANIA
}

\author{
Victoria Nistreanu', Dalia Paraschiv ${ }^{2}$, Alina Larion', Veaceslav Sitnic ${ }^{1}$ \\ ${ }^{1}$ Institute of Zoology, Chișinău, Republic of Moldova, victoria.nistreanu@zoology.md \\ 2Museum Complex of Natural Sciences “Ion Borcea”, Bacău, Romania, dalia_yvs@yahoo.com
}

\begin{abstract}
The studies were performed in the period 2008-2015 in orchards from the central part of the Republic of Moldova and Bacău County, Romania. In both areas 12 species rodent were registered, of which in central Moldova orchards the species $R$. norvegicus and P. subterraneus were not registered, while in Bacau orchards the species A. uralensis, M. rossiaemeridionalis and D. nitedula weren't recorded. In CM orchards the dominant species was $M$. rossiaemeridionalis with about $30 \%$, followed by $A$. sylvaticus and A. flavicollis. In BC orchards the dominant species was A. flavicollis with more that $41 \%$, followed by $A$. sylvaticus and $M$. arvalis. The analysis of demographic structure in spring period showed a high proportion of reproductive females in all species, being the highest at $M$. rossiaemeridionalis in CM orchard and in A. flavicollis in BC orchard. The share of young individuals constituted up to $40 \%$ depending on the species being the highest at $M$. rossiaemeridionalis in $\mathrm{CM}$ orchard and in A. flavicollis in $\mathrm{BC}$ orchard. A significant difference in the area of the individual sectors of M.rossiaemeridionalis males and females in the orchard in summer $(\mathrm{t}=3.46)$ and autumn $(\mathrm{t}=3.39)$ was established, as well as for A. sylvaticus in the spring and summer period $(\mathrm{t}=2.06 ; 2.03)$, and for A.uralensis in spring and autumn $(\mathrm{t}=2.99 ; 3.44)$.
\end{abstract}

\section{Introduction}

The rodents are the most spread group of mammals and quickly adapt to environmental changes. Therefore, they are important elements of terrestrial ecosystems, being the dominant vertebrate species in agricultural lands, such as orchards. The orchards, especially abandones ones provide favorable trophic and shelter conditions not only for field rodent, but also for forest rodent species, due to specific vegetation, formed by fruit trees, shrubs and various grass species. The monitoring of rodent communities is of high priority, because about $80 \%$ of the republic territory is occupied by agrocenoses $[6,10]$. In the central part of the Republic Moldova the agricultural landscape, including orchards, of which many abandoned, occupy large surfaces. The mosaic aspect of the agricultural landscape is particular for some areas of Bacau County, Romania. In both regions important areas are covered with natural or semi-natural forests, that contribute to the rather high diversity of small rodents in adjacent agrocoenoses, among which the orchards are the most favorable for the small rodent fauna. A comparative analysis of small rodent fauna of agricultural ecosystems from central part of the Republic of Moldova and from Bacau County was performed in the past years and revealed the influence of environmental conditions upon the diversity and structure of small rodent communities in several types of agrocenoses [5].

The aim of the study was to reveal the differences between the structure of small rodent communities in orchards from central part of Moldova and Bacau district, Romania. 


\section{Materials and methods}

The studies were performed in the period 2008-2018 in several orchards from the central part of the Republic of Moldova (CM) and Bacău County (BC). The most of the studied orchards from CM are abandoned, surrounded by other types of agrocoenoses, by pastures and forest belts (fig. 1). In BC the studied orchards were surrounded by other types of agrocoenoses (corn, vineyard) and by natural forest. The rodents were caught with snap traps and live traps, placed in lines at 5-8 m distance. The traps were baited with small bred pieces imbued with sunflower oil.

In order to characterize the biotopic distribution of the species the following indexes were considered: trappability $\mathrm{Cc}=100 \mathrm{n} / \mathrm{C}$, where $\mathrm{n}$ - number of individuals, $\mathrm{C}$ - number of traps; the frequency $\mathrm{F}=100 \mathrm{p} / \mathrm{P}$, where $\mathrm{P}$ - number of samples, $\mathrm{p}$ - samples where the species is present, and the species abundance $A=100 n / N$, where $n$ - number of individuals of a species in the sample, $\mathrm{N}$ - total number of individuals. The ecological significance was calculated (W) using the formula $\mathrm{W}=\mathrm{F} \cdot \mathrm{A} / 100$, where $\mathrm{F}$ is frequency of a species and $\mathrm{A}-$ abundance index. The species with the significance lower than $1 \%$ in the studied biocenoses are considered accidental; 1.1 - $5 \%$ - accessorial; 5.1-10\% - characteristic and $\mathrm{W}>10 \%$ - constant for the given biocenosis.

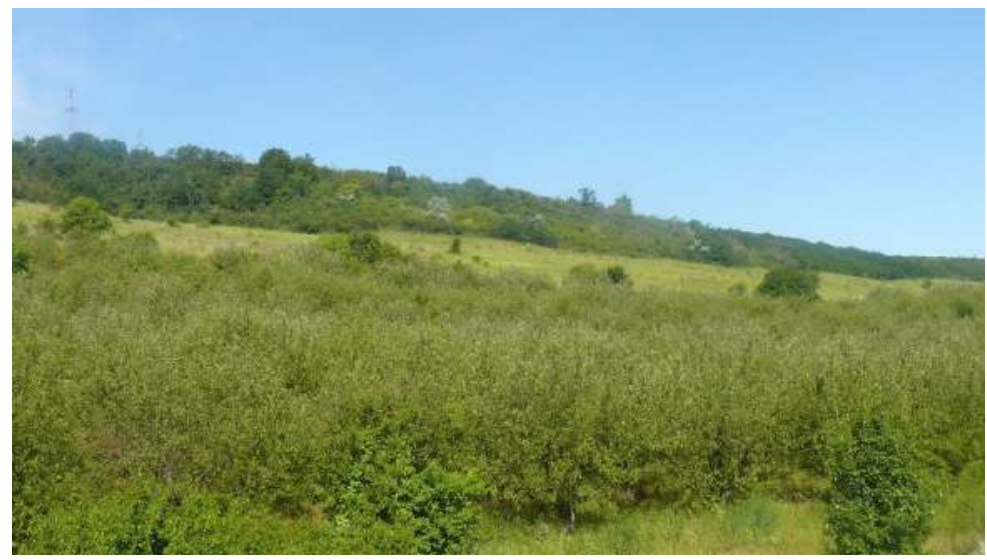

Figure 1. Abandoned plum and apple orchard limited by pasture and forest belt near Bacioi village, central part of the Republic of Moldova

The spatial structure of the rodent species was studied by the capture-mark-recapture method (CMR) according to standard methodology [11]. The method involves marking a number of individuals in a natural population, returning them to that population, and subsequently recapturing some of them as a basis for estimating the size of the population, the surface of the individual sectors, the migration process. During three study weeks there were processed 1500 trap-nights and marked more than 300 individuals by the method of the phalanx amputation [12].

The area of individual sectors and groups was calculated according to standard methods [2]. The size of the individual sectors was determined for individuals captured at least 3-4 times during a 5-day study. Individuals captured more than 3 times during a census were classified as 
"residents" and the rest - "migrants". By the method of exclusion at the border, the sizes of the individual sectors and the movement distance for the "resident" individuals were determined.

\section{Results and discussions}

In both areas 12 species were registered: Apodemus sylvaticus, A. flavicollis, A.uralensis, A. agrarius, Mus musculus, M. spicilegus, Rattus norvegicus, Microtus arvalis, M. rossiaemeridionalis, $M$. subterraneus, Clethrionomys glareolus and Dryomys nitedula. In CM orchards the species $R$. norvegicus and $M$. subterraneus were not registered, while in $\mathrm{BC}$ orchards the species $A$. uralensis, $M$. rossiaemeridionalis and $D$. nitedula weren't recorded. The presence of silvicolous species M. subterraneus in BC orhard can be explained by the proximity of the natural forest ecosystems. The brown rat can be met in cultivated lands situated near villages [1], though the species density was very low in the studied period (only one individual). In the CM the species M. rossiaemeridionalis is one of the dominant species in orchards and A. uralensis is very spread in various types of agricultural ecosystems, especially in adjacent pasture ecosystems [4, 8]. Although the forest dormouse occurs mostly in silvicolous habitat, it was often recorded in orchards with tree and bush vegetation, where it founds favorable conditions similar to the forest biotopes [4].

The species distribution in orchards from both studied areas showed some differences (fig. 2). Thus, in CM orchards the dominant species was $M$. rossiaemeridionalis with about 30\%, followed by $A$. sylvaticus and A. flavicollis, which constituted about $70 \%$ from the rodent community. In BC orchards the dominant species was A. flavicollis with more that $41 \%$, followed by $A$. sylvaticus and $M$. arvalis, which constituted over $80 \%$ from all rodent species (fig. 2). $A$. uralensis had a rather high percent in rodent community from CM orchard (more than 10\%), which confirm the data obtained in other studies [8]. The species A. agrarius reached almost $10 \%$ in $\mathrm{CM}$ orchard and only $4.4 \%$ in $\mathrm{BC}$ orchard. This fact is probably due to the differences in climatic conditions during the study period, especially in humidity degree, since the species prefers more humid environment. The proportion of $M$. spicilegus is rather close in both areas and usually do not overpass the abundance of $15-18 \%$ in orchards [3]. For M. musculus the orchard is not a very suitable habitat, because of high density of other rodent species and the proximity of localities, where it finds favorable conditions. Therefore, the species abundance was very low $(0.8-1.1 \%)$ in both studied areas. The silvicolous species $C$. glareolus is much more abundant in $\mathrm{BC}(6.6 \%)$ than in $\mathrm{CM}(2.3 \%)$ orchards, which is due to the existence of adjacent forest ecosystems in Bacau area. 


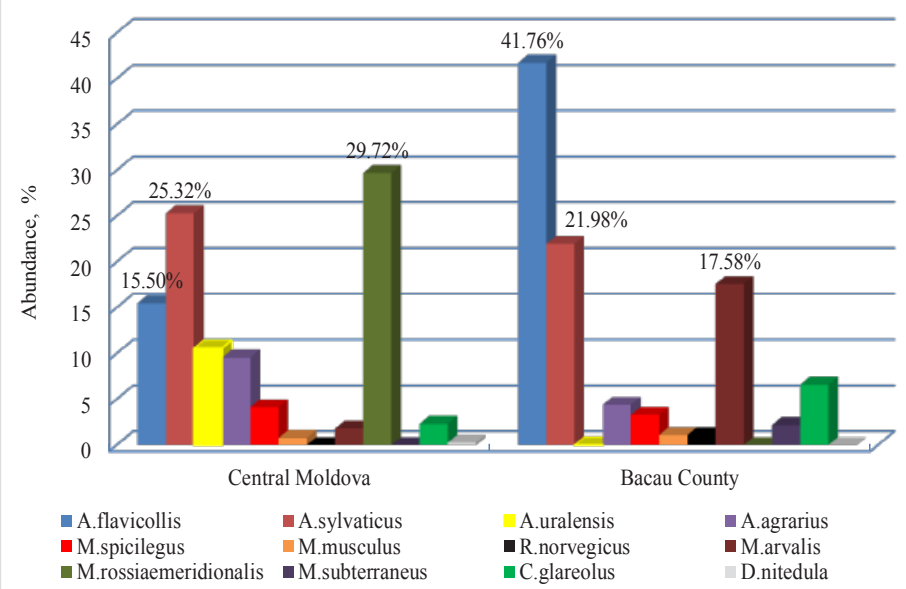

Figure 2. Rodent communities' structure in orchards from Central Moldova and Bacau County

The analysis of demographic structure in spring period (May-June) showed that $80.8 \%$ of M. rossiaemeridionalis population from orchard in CM are represented by breeding females and $22.8 \%$ of them belong to spring generation, which prove a very high reproductive potential. In the same period in BC orchard the reproductive females of $M$. arvalis constituted about half population and juvenile individuals constituted about 38.5\%. In A. sylvaticus from CM orchard the share of females was of $47.6 \%$ and from the $\mathrm{BC}-35.7 \%$, which prove a lower reproductive potential that the previous species. In $A$. uralensis the males were dominant with more than $70 \%$ and the species was represented only by adult individuals. In A.agrarius the female constituted $16.7 \%$ in CM orchard, while in BC they constituted more than $90 \%$ of the population. The subadult and juvenile individuals constitute about $20 \%$ in $\mathrm{CM}$ orchard and $16.7 \%$ in BC orchard. In A.flavicollis the share of females was of $41.9 \%$ in CM orchard and the young individuals constituted $44.4 \%$. In BC orchard the share of females was $42.86 \%$ and that of the subadults was about $40 \%$. The M.spicilegus reproductive females had a share of $25 \%$ and the proportion of young individuals - about $30 \%$, while in BC the species was not registered in spring period.

In the orchard from CM on a surface of one hectare during May-June and in September there were performed capture-mark-release studies in order to reveal the spatial structure of rodent community and its dynamics during the reproduction period. In May the dominant species was $M$. rossiaemeridionalis $(50.6 \%)$ of which individuals were dispersed on the whole surface. The recapture rate constituted $20.5 \%$ and the migrant individuals $-79.5 \%$. The individuals of the species A. flavicollis with a share of $20.1 \%$ formed 4 intrapopulation groups. The difference in the area of the individual sectors of adult overwintered males $(169.4 \pm 49.5 \mathrm{~m} 2)$ and those of the spring generation $(97 \pm 10.4 \mathrm{~m} 2)$ was significant $(\mathrm{t}=2.5, \mathrm{p} \leq 0.05)$. For females belonging to these generations, no significant difference in the area of the individual sectors was established $(\mathrm{t}=1.5, \mathrm{p} \leq 1.4) .54 .8 \%$ of the individuals were recaptured and the share of migrants was $45.2 \%$, of which $58.1 \%$ were males. In A. sylvaticus 3 intrapopulational groups were re- 
corded, the species population was formed by several unstructured groups and the individual sectors were little highlighted. A.uralensis individuals were marginalized in the upper part of the sector, being closer in the pasture. A. agrarius individuals formed two groups. In general, the surface of individual sectors was larger in males than in female, which was established in other studies $[4,7,9]$.

In June, the abundance of M.rossiaemeridionalis increased by $4.2 \%$ compared to May. $75.9 \%$ were breeding females, and $42.1 \%$ of individuals belong to the summer generation. The recapture rate of the individuals was of $43 \%$ and the migrants constituted $57 \%$, which was by $22.5 \%$ less than in the previous month of study. The share of $A$. flavicollis increased by 1.5 times and the individuals formed 5 intrapopulational groups. There was a significant reduction in the area of the individual sectors of adult males, their activity decreasing significantly $(\mathrm{t}=$ 2.07). The recapture rate of the individuals was of $68.9 \%$ and the share of migrants of $31.1 \%$. The individuals of $A$. sylvaticus formed four intrapopulational groups.

In the autumn period, a decrease in the abundance of M.rossiaemeridionalis species was established in the mark sector (21.4\%). The population of this species was formed entirely of young individuals, as well as the population of M. arvalis in BC orchard. In both study zones the dominant species was A.flavicollis with about 50\% in CM orchard and with $53.85 \%$ in BC orchard. Its abundance increased about 2.3 times compared to the previous study period. The A.uralensis population had a 3.7 time increase in abundance and an overwhelming share of young individuals $(95 \%)$. The share of marked and recaptured individuals from the previous period was of $28.6 \%$.

A significant difference in the area of the individual sectors of M.rossiaemeridionalis males and females in the orchard in summer $(\mathrm{t}=3.46)$ and autumn $(\mathrm{t}=3.39)$ was established, as well as for $A$. sylvaticus in the spring and summer period $(\mathrm{t}=2.06 ; 2.03)$, and for A.uralensis in spring and autumn $(\mathrm{t}=2.99 ; 3.44)$. In the orchard the reproductive groups appeared in late spring. The groups in A.sylvaticus are more numerous than in A.uralensis. In autumn these groups are more numerous than in spring and consisted of 5.2-8.3 individuals. In A.uralensis in spring-autumn period the males dominated (69-80\%), demonstrating the importance of this habitat as a refuge, especially for migrant males.

The studies were performed within the State Program project 20.80009.7007.02 and within collaboration agreement between Institute of Zoology, Republic of Moldova and Museum Complex of Natural Sciences "Ion Borcea”, Bacau, Romania.

\section{Conclusions}

In both areas 12 species were registered: Apodemus sylvaticus, A. flavicollis, A.uralensis, A. agrarius, Mus musculus, M. spicilegus, Rattus norvegicus, Microtus arvalis, M. rossiaemeridionalis, $M$. subterraneus, Clethrionomys glareolus and Dryomys nitedula. In CM orchards the species $R$. norvegicus and $M$. subterraneus were not registered, while in BC orchards the species A. uralensis, $M$. rossiaemeridionalis and D. nitedula weren't recorded.

The species distribution in orchards from both studied areas showed some differences. In 
CM orchards the dominant species was M. rossiaemeridionalis with about $30 \%$, followed by $A$. sylvaticus and A. flavicollis. In BC orchards the dominant species was A. flavicollis with more that $41 \%$, followed by $A$. sylvaticus and M. arvalis.

The analysis of demographic structure in spring period showed a high proportion of reproductive females in all species, being the highest at $M$. rossiaemeridionalis in CM orchard and in A. flavicollis in BC orchard. The share of young individuals constituted up to $40 \%$ depending on the species being the highest at $M$. rossiaemeridionalis in $\mathrm{CM}$ orchard and in A. flavicollis in $\mathrm{BC}$ orchard.

The recapture rate in the dominant species M. rossiaemeridionalis constituted $20.5 \%$ and the migrant individuals $-79.5 \%$. The differences between the area of individual sectors of males and females is significant in autumn period and have similar values in spring. The difference in the area of the individual sectors of overwintered males and those of the spring generation in the species A. flavicollis in May is significant, while in June there was a considerable reduction in the area of the individual sectors of adult males.

A significant difference in the area of the individual sectors of M.rossiaemeridionalis males and females in the orchard in summer $(\mathrm{t}=3.46)$ and autumn $(\mathrm{t}=3.39)$ was established, as well as for A. sylvaticus in the spring and summer period $(\mathrm{t}=2.06 ; 2.03)$, and for A.uralensis in spring and autumn $(\mathrm{t}=2.99 ; 3.44)$.

\section{Bibliography}

1. Burlacu, V., Nistreanu, V., Larion A. Caterinciuc, N. Structura comunităţilor de mamifere mici (Rodentia, Soricomorpha) în agrocenozele zonei de nord a Republicii Moldova. Buletinul Academiei de Ştiinţe a Moldovei. Ştiinţele vieţii. 2018, No 1(334), p. 126-133.

2. Metzgar L. H., Sheldon A. L. An indes of home range size. J. Wildlife Monog., 1974, V. 38, No 3 , p. $546-551$.

3. Munteanu A., Larion A., Savin A., Sîtnic V., Nistreanu V. Distribuţia biotopică şi raportul speciilor Mus spicilegus şi Mus musculus în agrocenoze. Sustainable use and protection af animal world diversity. International symposium dedicated to 75th anniversary of Professor Andrei Munteanu. Chişinău, 2014, 71-73.

4. Munteanu A., Savin A., Sâtnic V., Larion A., Nistreanu V. Ecologia rozătoarelor mici. Chișinău, Tip. „Căpățină Print”, 236 p.

5. Nistreanu V., Paraschiv D., Savin A., Larion A., Sitnic V. Comparative analysis of small rodent fauna in agrocenoses from central part of the Republic of Moldova and middle basin of Siret river, Bacau district, Romania. Studii și Comunicări. Complexul Muzeal „Ion Borcea”, Bacău, România, 2017, vol. 25, p. 98-102.

6. Nistreanu V., Savin A., Larion A., Sîtnic V., Chihai O. Ecological aspects of rodent communities in agrarian ecosystems of Moldova. Bulletin of University of Agricultural Sciences and Veterinary Medicine Cluj-Napoca. Volume 68, issue 1, 2011. p. 272-276.

7. Paraschiv D. Establishing the individual territory for some rodent populations in a hayfield from the Bereşti-Tazlău village, Bacău county. Studii și Comunicări. Complexul Muzeal „Ion Borcea", Bacău, România, 2017, vol. 25, p. 119-121.

8. Savin A. Distribuţia speciilor genului Apodemus (Rodentia, Muridae) în cenozele Republicii Moldova. Buletinul AŞM. Ştiinţe Biologice, Chimice şi Agricole, 2004, 4, p. 46-51.

9. Savin A. Structura şi dinamica grupărilor de Apodemus sylvaticus şi Apodemus microps în 
populaţiile din biotopurile natural. În: Diversitatea şi ecologia lumii animale în ecosisteme naturale şi antropizate. Chişinău, 1997, p. 24-26.

10. Savin A., Nistreanu V. Structural - functional transformations of rodent communities in ecosystems of Moldova against a background of anthropogenic and climatic changes. Oltenia Journal for Studies in natural Sciences, 2009, Tom. 25, No. 2, p. 275-280.

11. Stenseth N. C., Hagen A., Ostbye E., Skar H. J. A method forcalculating the size of the trappind area in capture-recapture studies on small rodents. Norw. J. Zool., 1974, V. 22, no 4, P. $253-271$.

12. Наумов Н. П. Мечение млекопитающих и изучение их внутривидовых связей. Зоологический журнал. Москва, 1956, Т.35, В.1, с. 3 -15. 